\title{
Lloyd R. Snyder: An Appreciation 1931-2018
}

\author{
Imre Molnár ${ }^{1}$
}

Published online: 19 November 2018

c) Springer-Verlag GmbH Germany, part of Springer Nature 2018

A few weeks ago, on the 19 September 2018, Lloyd R. Snyder, a genuine scientist and great chromatographer, passed away.

Born in 1931, Lloyd R. Snyder graduated in 1952 at the University of California at Berkeley in Chemistry. Early in his professional life he became involved in chromatography; his first job was to study the composition of petroleum at Shell Oil, where he became acquainted with the development of high-temperature gas chromatography, working together with Al Zlatkis.

He was even engaged in building his own gas chromatography unit. Later, he turned to solving a number of practical problems and tried to rationalize the large amount of data he generated. An early problem of column switching triggered his interest, in analyzing very complex mixtures, containing a large number of components, specifically gasoline samples from catalytic reformers, where no single column would provide a good resolution of these samples, due to limited peak capacity.

To aid the selection of mobile phases in the rapidly developing field of liquid chromatography, Lloyd arranged solvents in an eluotropic strength scale, based on the chromatographic behavior of selected solutes on silica columns, which involved a polar stationary phase and a less polar mobile phase. The work was supported by the "Solvent Triangle" principle and was used throughout the 1980s. His book with Jack Kirkland "Introduction to Modern liquid chromatography" became a bestseller.

In 1970, Lloyd was invited to join the editorial board of the Journal of Chromatography. In 1987, when the wellrespected chief editor Michael Lederer decided to retire, the position, which he had held since 1956, was offered to Lloyd. He accepted and remained chief editor until year 2000, when John Dorsey took his place, while Lloyd remained on the

Imre Molnár

imre.molnar@molnar-institute.com

1 Molnár-Institute for Applied Chromatography, Schneegloeckchenstrasse 47, 10407 Berlin, Germany editorial board. Lloyd was an editor with strong opinions on the theory of chromatographic retention and if he agreed to accept a paper that was a great honor for the author(s).

Csaba Horváth at Yale and Lloyd were also close friend. As Lloyd was working as the Research Director at Technicon, a clinical chemistry company, on a project on air segmented flow reactors, he visited Csaba several times to discuss some of the details of enzyme reactors for clinical purposes. I remember meeting him at Yale in the summer of 1976 for the first time- - I was a postdoc with Csaba-and I listened to discussions between both experts.

In 1981, Lloyd decided to return to his native West Coast and settled down in Orinda, CA, where he lived for the rest of his life. One of his neighbors was Erich Heftmann, originally from Vienna, both were working for Elsevier. Heftman edited the conference series of the Journal of Chromatography and would sit on a small table at the "Zlatkis meetings", which would later become the "HPLC-Symposium"-series. Sitting there, Erich collected the manuscripts from those who were presenting a paper or a poster.

Lloyd as an editor was assisted by two outstanding members of the editorial board of J. Chromatography: Hans Poppe and Georges Guiochon. They were both excellent reviewers. The journal also encouraged the production of a special issue, which Lloyd initiated and edited: "Computerassisted method development for high-performance liquid chromatography" (Volume 485, 1989).

After finishing my stay as a postdoc with Csaba Horváth, I started my research institute on 1st October 1981 in Berlin. It was Csaba, who saw the potential in a cooperation between Lloyd and myself. Together with Lloyd I taught several HPLC courses and from these activities we started to develop a software to support our courses. In 1983, Lloyd started "LC Resources Inc.", together with John Dolana former postdoc from Barry Karger's lab in Boston-and Tom Jupille as partners, offering HPLC short courses. Although in those days computers were at their infancy, we thought that this could be a business opportunity for the future. I became the European partner. In those days, nobody believed that something like this could be successful. An 
exception was Fritz Erni, director of R\&D at Novartis in Basel. He realized early the potential of software modeling. Other companies such as Pfizer and Sanofi followed him and the software raised more and more interest. The name DryLab was suggested by Lloyd, as opposed to the wet lab experiments with nitroglycerine he had performed as a young boy in the basement of the house of his parents, ending up in an explosion.

Regular exhibitions at different events, such as the Pittsburgh Conference (PittCon), Analytica and Achema, and scientific symposia, such as the HPLC- and ISC-meetings, were the places we would regularly meet.

Lloyd retired several times. One of the occasions was after he turned 70 years old: Elsevier arranged for him a great reception in Ellecom, in the Netherlands, to which many renowned scientists and friends were invited to (Fig. 1).

In 2006, DryLab was transferred to the Molnár-Institute and since that time further development has been carried out in Berlin.

Over the last 10 years, Lloyd worked on the "Hydrophobic Subtraction Database "with John Dolan, for column characterization to enable the selection of "equivalent "columns. This work created a Knowledge Space for HPLC columns and could be used in the comparison of different stationary phase materials based on similarities or on differences, contributing to the Quality by Design movement. This enabled the user to replace columns without a new validation. Today the database is part of DryLab4 and is also used by the USP.

The list of Lloyd's professional Honors shows the high appreciation of the scientific community for his extraordinary achievements:

American Chemical Society Award in Petroleum Chemistry (1970).

Steven Dal Nogare Memorial Award in Chromatography, Delaware Valley Chromatography Forum (1976).

Biography in 75 Years of Chromatography-A Historical Dialogue, Elsevier (1979).

Chromatography Memorial Medal, Scientific Council of the Academy of Sciences of the USSR (1980).

American Chemical Society Award in Chromatography (1984).

Pittsburgh Society Award in Analytical Chemistry (1984)

L. S. Palmer Award in Chromatography, Minnesota Chromatography Forum (1985)

A. J. P. Martin Award, the British Chromatographic Society (1989)

Northeast Regional Chromatography Discussion Group Award (1991).

Journal of Chromatography, 60th Birthday Honor Volume; Vol. 550 (1991).

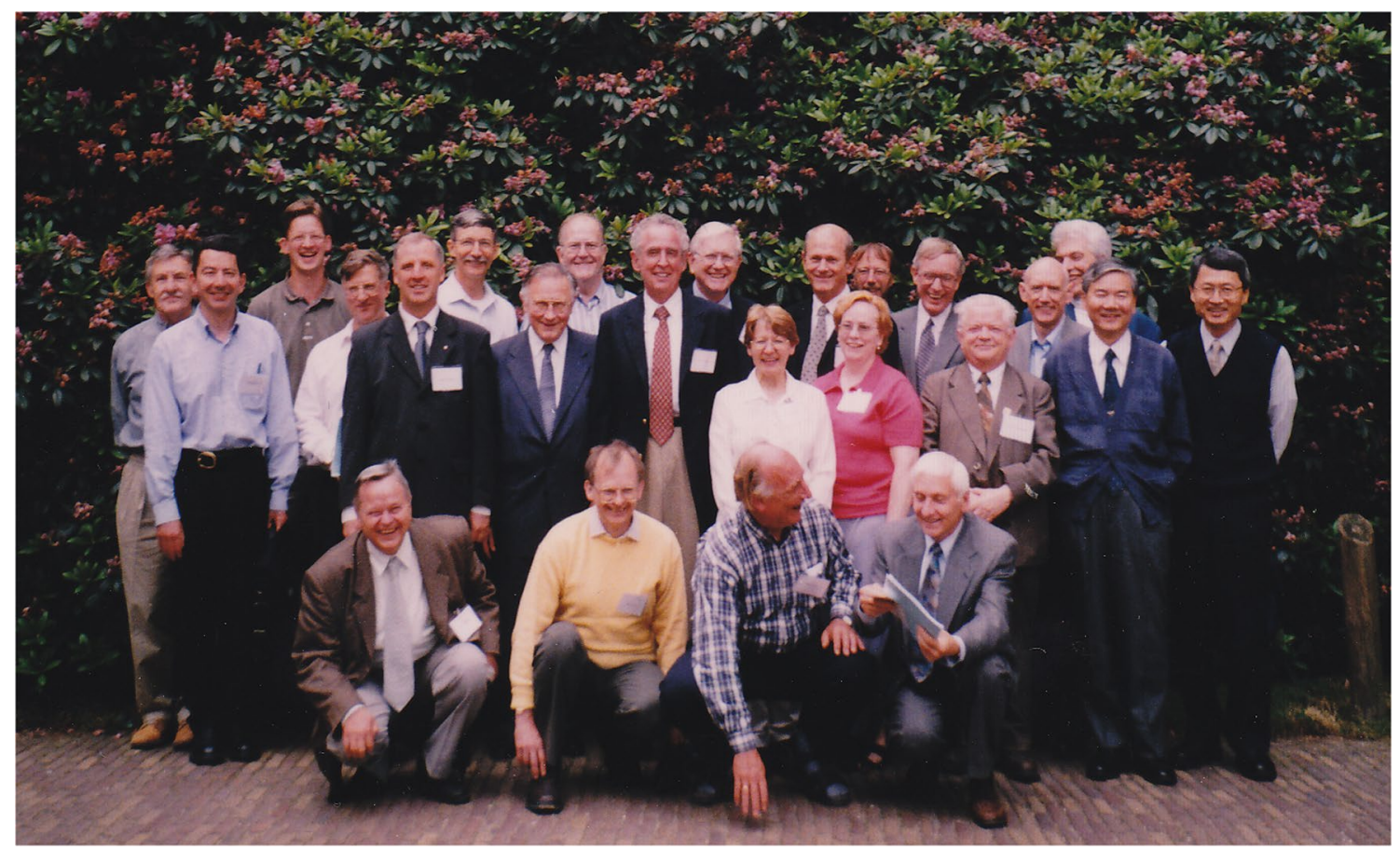

Fig. 1 A group photo with of Lloyd with his friends and colleagues in 2001 at his 70th Birthday. The event was organized by Elsevier in Ellecom in the Netherland. Top row: Peter Schoenmakers, John Dolan, Peter Carr, Lloyd Snyder, Imre Molnár, Jack Kirkland, Imre
Molnár, Klaas Bij, John Dorsey, Roger Giese, Rob Marx, Shigeru Terabe, Nobuo Tanaka; Middle row: Erich Heftmann, David McCalley, Gyula Vigh, Roman Kaliszan, Csaba Horváth, Sandra Poole, Sarah Rutan, Edward Soczewinski 
American Chemical Society, Orange County Section "Service Through Chemistry "Award (1993).

Eastern Analytical Symposium Award in Separation Science (1994).

Recognition of five "HPLC pioneers"; award at HPLC'95 in Innsbruck, as reported in J. Chromatogr. A, 703 (1995) 2.

James L. Waters Sixth Annual Symposium recognizing four Pioneers in the Development of Analytical Instrumentation (High Performance Liquid Chromatography); organized by the Society for Analytical Chemists of Pittsburgh (1995).

California Separation Science Society Award for Distinguished Contributions inSeparation Science (1996).

Anachem Award (Association of Analytical Chemists) (1998).

Memorial Medal of the Medical University of Gdansk (2001).

Biography in Chromatography - A Century of Discovery, 1900-2000, Elsevier (2002).

Csaba Horváth Medal, Connecticut Separation Science Council (2005).

Chicago Chromatography Discussion Group Merit Award (2005).

Waksmundzki Medal of the Polish Analytical Society (2005).
Member, Honorary Editorial Board of the Journal of Chromatography A (2009).

Lifetime Achievement in Chromatography Award of LCGC North America (2012).

The work of Lloyd Snyder will survive him for many generations to come: His excellence in teaching HPLC and his contributions to the theory of chromatography, especially in gradient elution, will be a great help for young scientists in the future. His contributions to modeling HPLC, which is used now in almost every pharmaceutical company, at the FDA and other regulatory agencies, essentially supports the understanding of chromatographic principles.

Lloyd Snyder was a true friend and a wonderful human being. He was always actively participating in all relevant scientific questions, answered fast and was driving science forward with great enthusiasm. We all will miss him in the scientific community very much.

God bless you, Lloyd, rest in peace! Imre Molnár 